\title{
Tag and recapture of European hake (Merluccius merluccius L.) off the Northwest Iberian Peninsula: First results support fast growth hypothesis
}

\author{
Carmen Piñeiro $^{\mathrm{a},{ }^{*}}$, Javier Rey ${ }^{\mathrm{b}}$, Helene de Pontual ${ }^{\mathrm{c}}$, Raquel Goñi ${ }^{\mathrm{d}}$
}

\author{
${ }^{\mathrm{a}}$ Instituto Español de Oceanografía, Centro Oceanográfico de Vigo, Apdo. 1552, 36200 Vigo, Spain \\ ' Instituto Español de Oceanografía, Centro Oceanográfico de Málaga, Puerto pesquero s/n, 29640 Fuengirola, \\ Spain \\ 'IFREMER, Laboratoire de Sclérochronologie des Animaux Aquatiques, STH/LASAA, BP 70, F-29280 Plouzané, \\ France \\ dInstituto Español de Oceanografía, Centro Oceanográfico de Baleares, P.O. Box 291, 07080 Palma de Mallorca, \\ Spain
}

*: Corresponding author : Carmen Piñeiro, email address : carmen.pineiro@vi.ieo.es

\begin{abstract}
:
In the first tagging experiment of European hake (Merluccius merluccius L.) conducted off the NW Iberian Peninsula to study hake growth in the wild we released 527 live tagged individuals. The survival rate after capture and tagging was $58 \%$. Mortality during capture was positively correlated with depth of capture and negatively correlated with hake size. Fifteen months after tagging, seven individuals (1.3\%) had been recaptured with times at liberty ranging from 29 to 466 days. We provide the first direct measurements of growth rates of Southern stock European hake in the wild and compare them with rates obtained from tagging experiments in other regions and with rates derived from conventional otolith age reading. The mean somatic growth rate of all recaptured hake was 0.032 $\pm 0.016 \mathrm{~cm}$ day -1 (sexes combined), while the mean growth rate of the two hake with over 340 days at liberty was $0.052 \pm 0.003 \mathrm{~cm}$ day-1 (sexes unknown). These results indicate that conventional otolith age reading methods overestimate age and underestimate growth.
\end{abstract}

Keywords: European hake; Growth rates; Tag-recapture; Age estimation; Northeast Atlantic 


\section{1. Introduction}

The European hake Merluccius merluccius L. is widely distributed throughout

3 the Northeast Atlantic and Mediterranean and reaches greatest density between the

4 British Isles and the Southern Iberian Peninsula (Casey and Pereiro, 1995). It is one of

5 the most valuable and heavily exploited demersal species in Western European

6 fisheries. The status of $M$. merluccius populations in the NE Atlantic is assessed

7 annually by the International Council for the Exploration of the Sea (ICES) on the basis

8 of two separate stocks, the Northern stock and the Southern stock, to the north and south

9 of Cape Breton Canyon (Bay of Biscay) respectively (ICES, 1979). Recent assessments

10 of the status of the Southern stock (Spanish and Portuguese waters) reveal a dramatic

11 decline of the spawning stock biomass that has been attributed to overfishing (ICES,

12 2006). Despite numerous studies focusing on the biology of $M$. merluccius (see Piñero

13 and Saínza, 2003 for a review), many gaps remain in our knowledge on the species. In

14 particular, there is a lack of knowledge on the growth rate, which is vital for population

15 assessment using age-based models. Problems with hake otolith interpretation and age

16 estimation have to date hindered efforts to produce reliable age length keys for age-

17 based models (Piñeiro and Saínza, 2003).

18 One of the most reliable methods of validating the growth of fishes is tagging 19 and recapturing individuals in nature (Campana, 2001). Until recently few tagging 20 experiments of hake had been conducted due to the poor survival of individuals 21 captured by conventional methods (Belloc, 1935; Robles et al., 1975; Lucio et al., 22 2000). In 2002 a new trawl gear specially designed for the capture of live individuals 23 was successfully tested by de Pontual et al. (2003). The survival rate after capture and 24 tagging was $68 \%$ and the rate of recapture after three years was $3.1 \%$. The results of that 
1 experiment indicated that the rate of somatic growth of Northern stock hake was two

2 times higher than predicted by current growth models derived from internationally

3 agreed otolith ageing criteria (de Pontual et al. 2006). Internationally agreed criteria for hake otolith interpretation and age estimation,

5 summarized by Piñeiro and Saínza (2003), have never been validated and have been

6 questioned by the first results of Northern stock hake tag-recapture experiments (de

7 Pontual et al., 2003, 2006) as well as by ICES (ICES, 2005). Here we present estimates

8 of somatic growth rates obtained from the first successful tag-recapture experiment of

9 Southern stock hake and compare them with growth rates obtained by conventional 10 ageing criteria, as well as with those derived from tag-recapture experiments of 11 Northern stock hake (Belloc, 1935; Lucio et al., 2000; de Pontual et al., 2003; 2006).

\section{Material and Methods}

Tagging was carried out in September-October 2004 off the NW Iberian

15 Peninsula at depths from 40-130 m Locations of capture, release and recapture are 16 shown in Figure 1. The fishing gear, a trawl (GOC-73) modified with a specially 17 designed cod-end, and the handling method were as described in de Pontual et al. 18 (2003). All hake were measured (total length, TL) and individuals $<40 \mathrm{~cm}$ TL were 19 tagged with FF-94 Floy ${ }^{\circledR}$ anchor tags while individuals $\geq 40 \mathrm{~cm}$ TL were tagged with 20 the larger FD-94 Floy ${ }^{\circledR}$ anchor tag. All hake were also tagged internally by injection 21 with Terramicine ${ }^{\circledR}$ (OTC) at a dosage of $60 \mathrm{mg}^{*} \mathrm{~kg}^{-1}$, using the length-weight 22 relationship $W_{t}=0.00733 L^{2.981}$ (Piñeiro and Saínza, 2003). Tagged hake were released 23 in two locations selected to keep the animals temporarily safe from commercial fishing 24 operations (Figure 1). The release was done through a smooth PVC pipe while seabirds 
1 were scared away to minimize predation. Recaptures came from commercial tangle-net

2 and bottom trawl hake fisheries operating in the region. Whenever possible, recaptured

3 individuals were measured and sexed, while the otoliths were removed for growth

4 analysis based on the Terramicine ${ }^{\circledR}$ mark laid down at the time of tagging.

5 Somatic growth from release to recapture was computed for each recaptured

6 individual. Mean growth rates were estimated for all the recaptures combined and

7 separately for two recaptures with times at liberty $>340$ days. Survival rates after

8 capture and after tagging were calculated and their relationship with fishing depth was

9 investigated by logistic regression analysis. Mortality due to seabird predation was

10 estimated by eye.

\section{Results}

A total of 1131 hake were caught in 45 fishing sets (Figure 1.). The proportion

14 of hake alive in the catch was $58 \%$, of which $80 \%$ survived the tagging process. In total

15527 hake (46.6\% of the catch) were returned tagged to the sea. We estimated that about $10 \%$ of the released fish were affected by seabird predation.

The size structure of hake in the catch ranged from 7 to $61 \mathrm{~cm}$ TL and had two

18 distinct groups with modal sizes of 15 and $30 \mathrm{~cm}$ TL (Figure 2). The proportion of hake

19 dead in the first group was greater than in the second, suggesting a negative relationship

20 with size (Figure 2). Mortality rates during capture and tagging were positively correlated with depth of capture, which explained $72 \%$ and $98 \%$ of their variation

22 respectively $\left(r^{2}=0.72, p=0.07 ; r^{2}=0.99, p<0.01\right)$. However, the correlation between

23 fishing depth and hake size, the smaller hake being more abundant at greater depth,

24 precluded contrast across the two effects. 
2 one tag was recovered without the fish, resulting in a recapture rate of $1.3 \%$ (Table 1 ).

3 The time between release and recapture ranged from 29 to 466 days and the distance

4 moved from release to recapture ranged from 1 to 14.7 nautical miles (Table 1, Figure $51)$.

6 The mean growth rate $( \pm \mathrm{SD})$ of recaptured fish was $0.032 \pm 0.016 \mathrm{~cm} \mathrm{TL} *$ day- ${ }^{1}$ $7 \quad(n=6$, sexes combined), while that of the individuals recaptured within three months of 8 release was $0.021 \pm 0.003 \mathrm{~cm} \mathrm{TL} * \mathrm{day}^{-1}(\mathrm{n}=4$, sexes combined). The mean growth rate 9 of the two specimens that had spent over 340 days at sea was $0.052 \pm 0.003 \mathrm{~cm}$ TL*day101 (Table 2).

\section{Discussion}

The first tagging trial of Southern stock hake was carried out off the NW Iberian

14 Peninsula by Robles et al. in 1975. This experiment confronted high mortality and 15 yielded no recaptures. Almost 30 years later, results of the second tag-recapture 16 experiment in the region confirm the suitability of the method developed and 17 successfully tested in the northern Bay of Biscay by de Pontual et al. (2003). In our experiment the survival rate after capture (58\%) was lower than in Pontual et al. (2003)

19 (68\%), but survival rates can be improved in future surveys by targeting hake in shallow 20 waters, thus reducing barometric stress, and by using a device to limit the size of the 21 catch in the cod-end. The relatively low recapture rate of $1.3 \%$, in comparison with that 22 obtained by de Pontual et al. (2006) of 3.1\%, may be partially attributed to the limited 23 geographic scope of our publicity campaign to fishermen and to the lack of an economic 24 reward for the return of tagged individuals. 
In spite of the many efforts devoted to age estimation of $M$. merluccius over the

2 years (see Piñeiro and Saínza, 2003 for a review), interpretation of otolith ring patterns

3 remains controversial and uncertainty about the reliability of age estimates has not

4 declined. Direct measures of growth derived from mark-recapture experiments provide

5 invaluable data for the resolution of this problem. Until now, these data were only

6 available for Northern stock hake. Here for the first time we provide direct measures of

7 the growth rate of Southern stock hake. Our results support the fast growth model

8 proposed by de Pontual et al. (2006) for Northern stock hake by which M. merluccius

9 reach about 25, 45 and $60 \mathrm{~cm} \mathrm{TL}$ at the end of the first, second and third year of life,

10 instead of 20, 29 and $37 \mathrm{~cm}$ TL as estimated from otoliths using the internationally

11 agreed age interpretation method (Piñeiro and Saínza, 2003). The striking consistency

12 between our results and somatic growth rates from tag recoveries of Northern stock

13 hake (Figure 3) is of prime interest because concurs with genetic studies which do not

14 find significative differences between both stocks (Cimmaruta et al., 2005). Although

15 earlier tagging studies had very low tag return rates (Belloc, 1935; Lucio et al., 2000),

16 their findings also indicate a much faster growth rate of this species (Table 2).

17 The mean daily growth of individuals recaptured within three months (fall season) was less than half that of the hake recaptured after nearly one year at sea. This

19 discrepancy may be due to seasonal variations in growth (Norbis et al. , 1999; Morales-

20 Nin and Moranta, 2004), although short-term growth slow-down as a result of capture 21 and tagging stress cannot be discounted.

Interestingly, the fast growth of this species had been repeatedly hypothesized,

23 first by Bagenal (1954) on the basis of otolith readings and size frequency data and later 24 by Piñeiro and Pereiro (1993) and Alemany and Oliver (1995) on the basis of size 
1 modal progression analysis, by Riis-Vestergaard et al. (2000) based on consumption

2 rates and bioenergetic requirements, and by Kacher and Amara (2005) based on daily

3 growth. A further indication of the failure of current otolith age estimation procedures is

4 the lack of coherent evolution of cohorts in age structured models used by ICES (ICES, 5 2005).

6 In sum, our results coincide with all available tag-recapture data to indicate that 7 the growth rate of European hake in the size range studied is about double that derived 8 by the conventionally accepted and routinely applied otolith age interpretation method.

9 We expect that these results will contribute to the discussion on European hake 10 population dynamics as recent work by Bertignac and de Pontual (2007) has shown how 11 bias in age estimations affect assessments of Northern stock hake. Our results thus emphasize the need to carry out large-scale tagging experiments covering the main

13 geographic range of the species in order to develop new, validated ageing criteria for 14 routine age estimation.

\section{Acknowledgements}

We are grateful to all participants in the tagging experiment (MARMER0904), to the skippers and fishermen from the littoral region of A Coruña who provided invaluable information for our survey, especially to those who generously returned tagged fish. We wish to thank M. Marín and F. Saco for their technical assistance and U. Autón and A. Vazquez for their collaboration in the recaptures. Finally, we want to acknowledge F. Velasco and P. Oliver for useful comments on the manuscript. 


\section{References}

2 Alemany, F., Oliver, P., 1995. Growth of female hake in the Balearic Sea: A proposal of new growth model with higher growth rates. Rapp. Comm. int. Mer Médit, 34.

4 Bagenal, T.B., 1954. Growth rate of the hake (Merluccius merluccius L.) in the Clyde and other Scottish areas. J. Mar. Biol. Assoc. U.K., 33: 69-95.

6 Belloc, G., 1935. Etude monograhique du merlu Merluccius merluccius L.. 3ème partie. 7 Rev. Trav. Off. Pêches marit, 8: 145-202.

8 Bertignac, M., de Pontual, H., 2007. Consequences of bias in age estimation on assessment of the northern stock of European hake (Merluccius merluccius) and on management advice. ICES J. Mar.Sci. 64: 981-988.

11 Campana, S. E., 2001. Accuracy, precision and quality control in age determination, including a review of the use and abuse of age validation methods. J. Fish. Biol. 59:197-202.

Casey, J., Pereiro, F.J., 1995. European hake (M. merluccius) in the North-east Atlantic. In: Alheit, J., Pitcher, T. J. (Eds.), Hake: Biology, Fisheries, and Markets.

17 Cimmaruta, R., Bondanelli, P., Nascetti, G., 2005. Genetic structure and environmental heterogeneity in the European hake (Merluccius merluccius). Molecular Ecolgy.14: 2577-2591.

de Pontual, H., Bertignac, M., Battaglia, A., Bavouzet, G., Moguedet, P., Groison, A.L., 2003. A pilot tagging experiment on European hake (Merluccius merluccius): methodology and preliminary results. ICES J. Mar.Sci. 60: 1318-1327.

de Pontual, H., Groison, A.L., Piñeiro, C., Bertignac, M., 2006. Evidence of underestimation of European hake growth in the Bay of Biscay, and its 
relationship with bias in the agreed method of age estimation. ICES J. Mar.Sci. 63: $1674-1681$.

3 ICES., 1979. Report of the Working Group on Assessment of hake stocks. ICES C.M. 1979/G:27.

ICES., 2005. Report of the Working Group on the Assessment of Southern Stocks of Hake, Monk, and Megrim. ICES C.M. 2005/ACFM: 02.

ICES., 2006. Report of the Working Group on the Assessment of Southern Shelf Stocks of Hake, Monk and Megrim. ICES C.M. 2006/ACFM: 29.

9 Kacher, M., Amara, R., 2005. Distribution and growth of 0-group European hake in the Bay of Biscay and Celtic Sea: a spatial and inter-annual analyses. Fish. Res. 71: 373-378.

Lucio, P., Santurtun, M., Quincoces, I., 2000. Tagging experiments on hake, anglerfish and other species in the Bay of Biscay. ICES C.M. 2000/Z:09.

Morales-Nin, B., Moranta, J., 2004. Recruitment and post-settlement growth of juvenile Merluccius merluccius on the western Mediterranean shelf. Scientia Marina, 68 (3): 399-409.

Norbis, W., Lorenzo, M.I., Torres, G. J., 1999. Intra-annual growth variations of young of the year hake (Merluccius hubbsi) of the Uruguayan continental shelf based on otolith analysis. Fish. Res. 44: 129-137.

Piñeiro, C.G., Pereiro, J. A., 1993. Study on juvenile growth pattern of European hake (Merluccius merluccius L.) using whole otoliths and length frequency distributions from commercial catches and fish surveys. ICES C.M. 1993/G: 12, $14 \mathrm{pp}$. 
1 Piñeiro, C., Saínza, M., 2003. Age estimation, growth and maturity of the European 2 hake, (Merluccius merluccius Linnaeus,1758) from Iberian Atlantic waters. ICES J. Mar.Sci. 60: 1086-1102.

4 Robles, R., Pereiro, J.A. Fernandez, A.M. García., J. M., 1975. Estudios de cartografía, selectividad y marcado de merluza europea, (Merluccius merluccius L.), frente al litoral Gallego. Bol. Ins.Esp. Oceanog. 190: 1-39.

7 Riis-Vestergaard, J., Velasco, F., Hill, L. , Olaso, I., 2000. Food consumption of 8 European hake (Merluccius Merluccius L.) estimated by application of a bioenergetics model: Is the growth of hake underestimated?. 9ICES C.M. 2000/Q:12, Ref. R.

11 


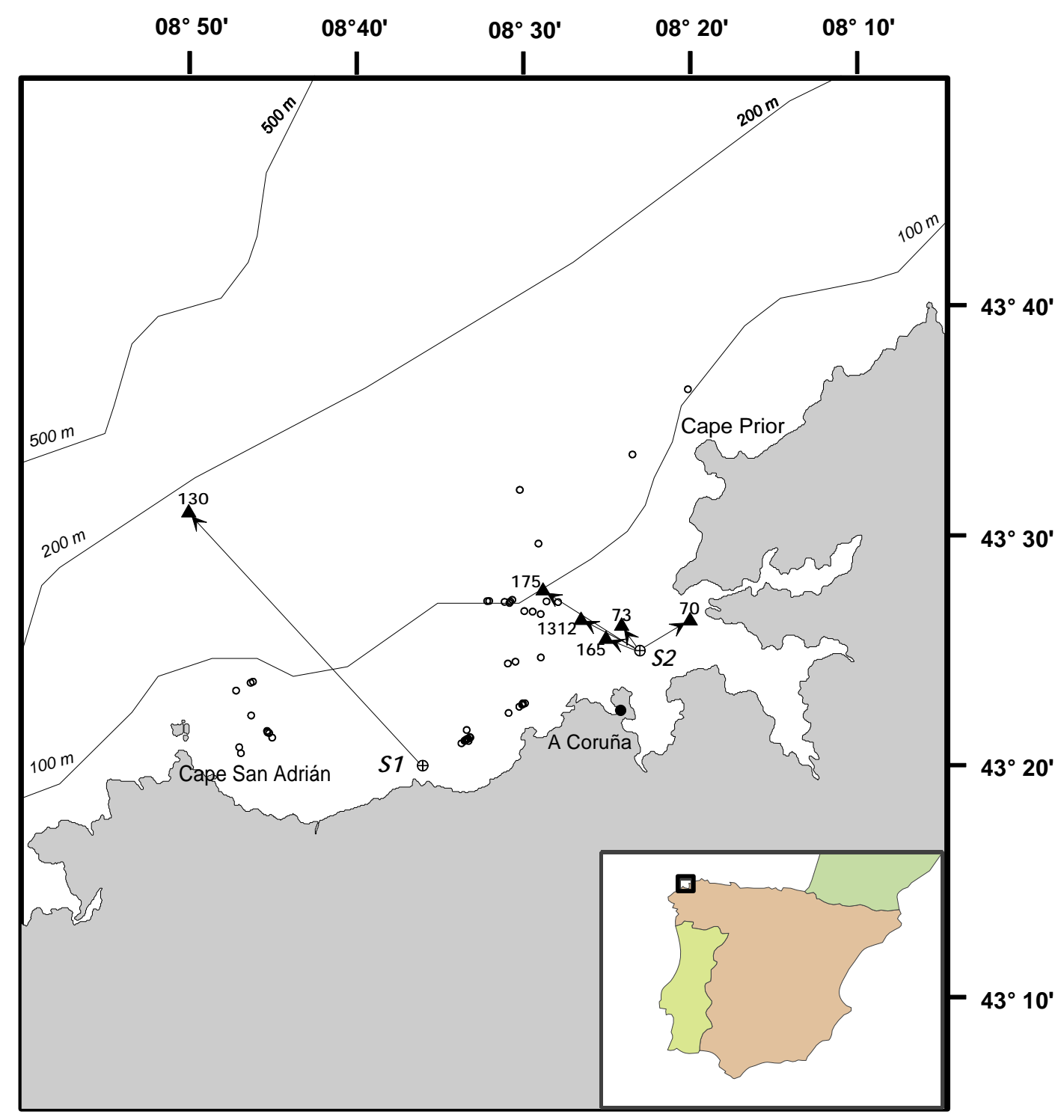

Fig. 1. Study area indicating capture (circles), release (cross circles S1, S2) and recapture (triangles) locations with fish codes. 


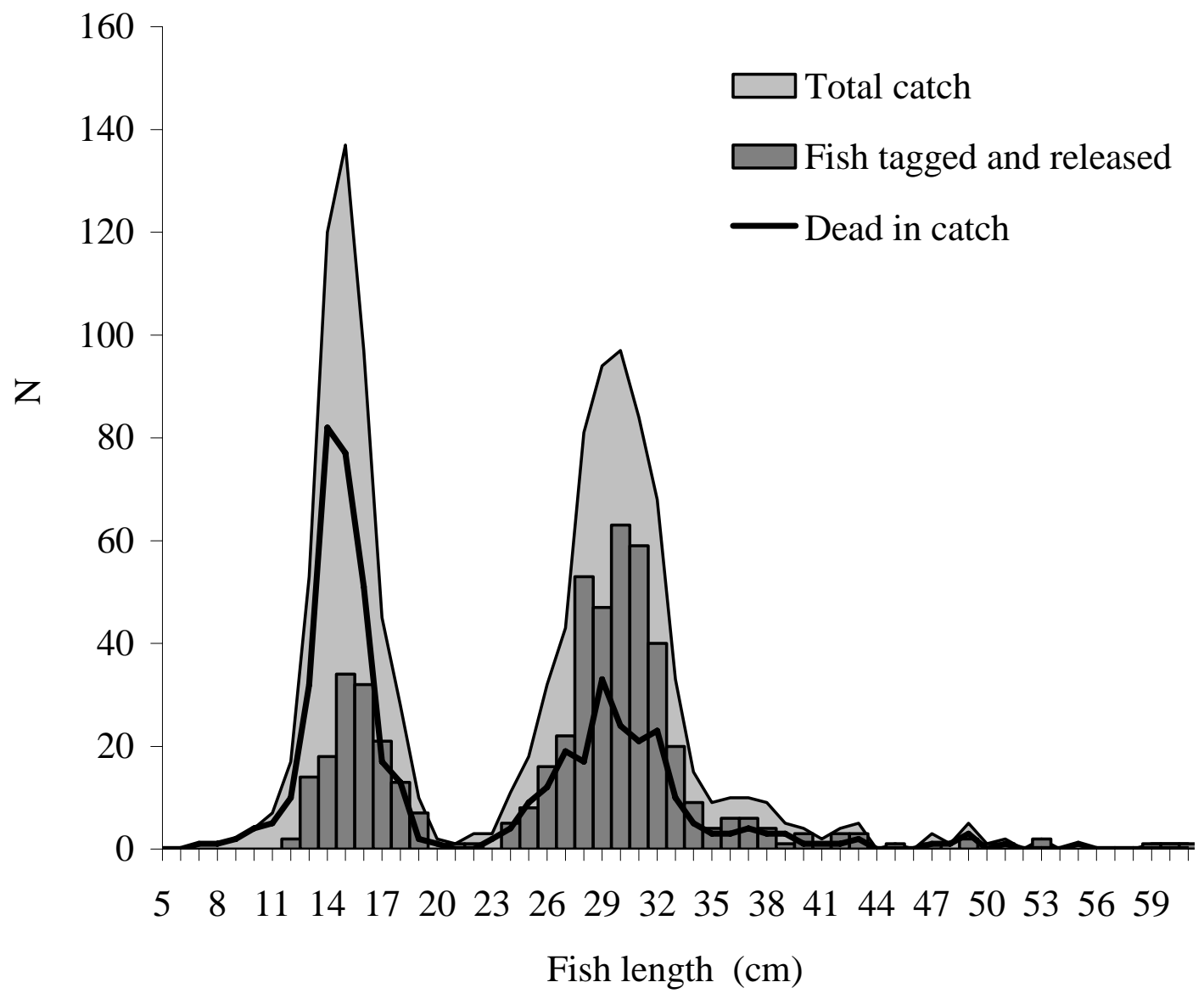

1

2

3 Fig. 2. Size frequency distributions (N) of the total catch, dead after captured fish and tagged4 released fish.

5

6

7

8

9 


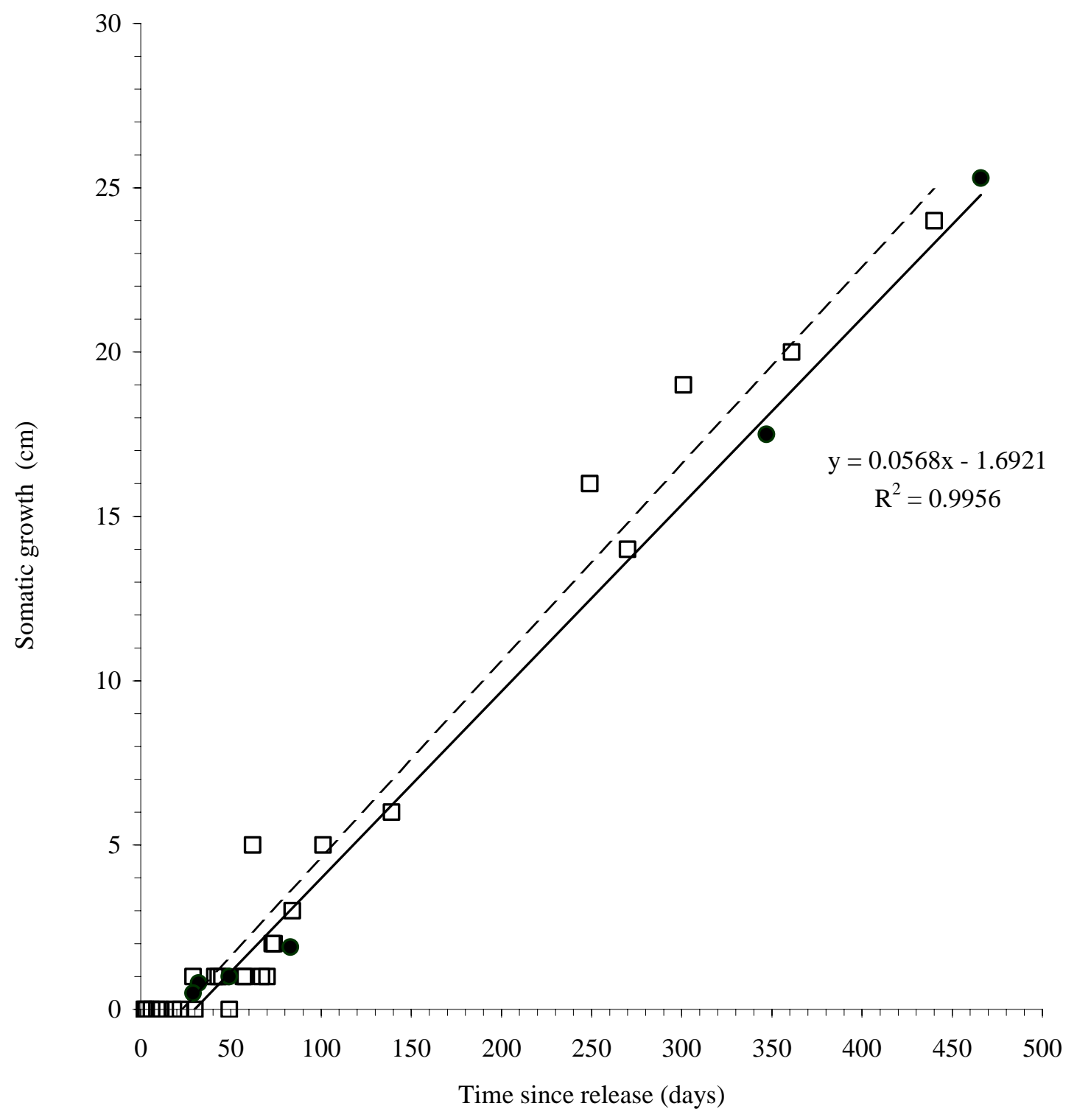

18 Fig. 3. Somatic growth increment (TL, $\mathrm{cm})$ as a function of time since release. Black dots and solid

19 line: this study; squares and dashed line: data of Northern stock hake (de Pontual et al. 2006)

20 restricted to comparable time period (up to 500 days since release). 
Table 1

Tag-recapture information of hake tagged during the experiment. M: male; F: female;

$\mathrm{U}$; unknown (gutted)

\begin{tabular}{|c|c|c|c|c|c|c|c|c|c|}
\hline \multicolumn{4}{|c|}{ Tagging data } & \multicolumn{5}{|c|}{ Recapture data } & \multirow[b]{2}{*}{$\begin{array}{c}\mathrm{TL} \\
\text { increment } \\
\text { (cm) }\end{array}$} \\
\hline $\begin{array}{l}\text { Fish } \\
\text { Code }\end{array}$ & Date & $\begin{array}{l}\text { Depth } \\
\text { (m) }\end{array}$ & $\begin{array}{c}\mathrm{TL} \\
(\mathrm{cm})\end{array}$ & Date & $\begin{array}{l}\text { Time since } \\
\text { release } \\
\text { (days) }\end{array}$ & $\begin{array}{c}\text { Distance } \\
\text { (nautical } \\
\text { miles) }\end{array}$ & $\begin{array}{l}\mathrm{TL} \\
(\mathrm{cm})\end{array}$ & Sex & \\
\hline 165 & $04 / 10 / 04$ & 61 & 30.7 & $03 / 11 / 2004$ & 29 & 1.04 & 31.2 & $\mathrm{U}$ & 0.5 \\
\hline 1312 & $02 / 10 / 04$ & 63 & 30.7 & $04 / 11 / 2004$ & 32 & 4.48 & 31.5 & $\mathrm{~F}$ & 0.8 \\
\hline 70 & 03/10/04 & 61 & 31.1 & $22 / 11 / 2004$ & 49 & 2.45 & 32.1 & $\mathrm{~F}$ & 1 \\
\hline 149 & 04/10/04 & 61 & 36.2 & 29/11/2004 & 55 & - & No fish & - & No fish \\
\hline 73 & 03/10/04 & 61 & 32.2 & $26 / 12 / 2004$ & 83 & 1.09 & 34.1 & $\mathrm{~F}$ & 1.9 \\
\hline 130 & 04/10/04 & 61 & 29 & 21/09/2005 & 347 & 14.7 & 46.5 & $\mathrm{U}$ & 17.5 \\
\hline 175 & 04/10/04 & 61 & 30.7 & 20/01/2006 & 466 & 2.45 & 56 & $\mathrm{U}$ & 25.3 \\
\hline
\end{tabular}




\section{Table 2}

Summary of results of available tag-recapture studies of European hake. *: only tag (no fish) recaptured. **: information of fish that were $>100$ days at sea. $(N S=$ Northern Stock; $S S=$ Southern Stock $)$

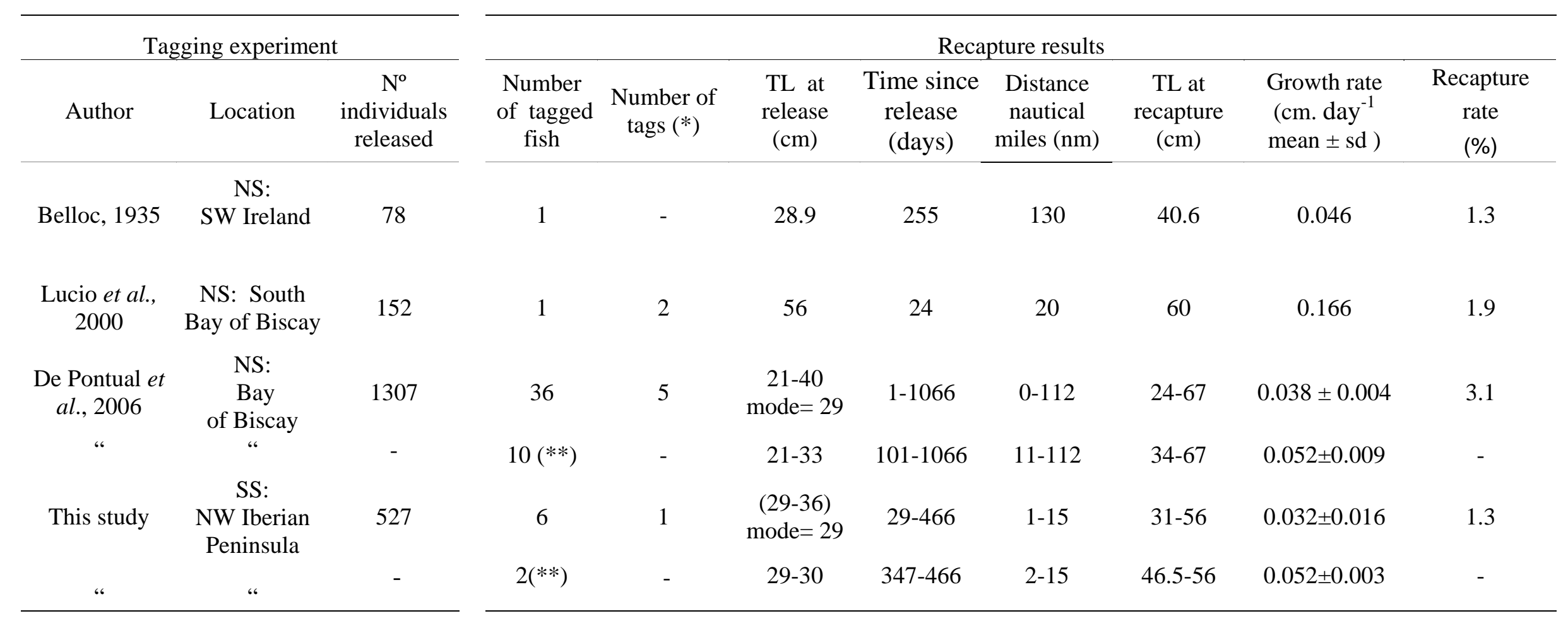

